\title{
PRODUKSI DAN KANDUNGAN NUTRISI Spirulina fusiformis YANG DIKULTUR DENGAN PENCAHAYAAN MONOKROMATIS LIGHT EMITTING DIODES (LEDs)
}

\author{
Muhammad Firdaus" \# dan Ahmad Fauzan ${ }^{\text {***) }}$ \\ ") UPT Loka Pengembangan Bio Industri Laut, Pusat Penelitian Oseanografi, LIPI \\ ") PT Suri Tani Pemuka (JAPFA Group)
}

(Naskah diterima: 18 April 2015; Revisi final: 6 Mei 2015, Disetujui publikasi: 5 Juni 2015)

\begin{abstract}
ABSTRAK
Spirulina merupakan mikroalga yang digunakan secara luas sebagai bahan baku industri kimia, pangan, dan pakan. Produksi dan kandungan biokimia produk yang dihasilkan sangat berkaitan dengan kondisi kultur, antara lain spektrum cahaya yang digunakan. Pencahayaan monokromatis dengan panjang gelombang tertentu yang dihasilkan light emitting diodes (LEDs) berpotensi untuk diaplikasikan pada mikroalga. Penelitian ini bertujuan untuk mengkaji pengaruh panjang gelombang cahaya dari LEDs terhadap produksi dan kandungan nutrisi Spirulina fusiformis. Spirulina dikultur dengan intensitas cahaya 2.000 Lux yang bersumber dari LED dengan cahaya monokromatis merah (M), biru (B), dan biru-merah (BM), serta cahaya dari lampu fluoresens sebagai kontrol (K). Puncak kepadatan sel terjadi pada hari ke-18 dengan kepadatan masing-masing sebanyak 5,56 x $10^{4} \mathrm{sel} / \mathrm{mL}(\mathrm{M}) ; 1,65 \times 10^{4} \mathrm{sel} / \mathrm{mL}$ (B); 4,15 x 104 $\mathrm{sel} / \mathrm{mL}$ (BM); dan $4,56 \times 10^{4} \mathrm{sel} / \mathrm{mL}(\mathrm{K})$. Perlakuan pencahayaan LED dengan cahaya monokromatis merah mencapai biomassa panen tertinggi sebesar 3,91 mg/mL dengan kandungan protein 49,77\%; lemak 19,61\%; karbohidrat 6,15\%; serat kasar 0,00\%; dan abu 24,48\%. Pencahayaan dengan LED merah berpotensi diaplikasikan sebagai sumber cahaya dalam produksi Spirulina.
\end{abstract}

KATA KUNCI: Spirulina fusiformis, LEDs, lampu fluoresens, produksi, kandungan nutrisi

ABSTRACT: Production and nutritional value of Spirulina fusiformis cultured with light emitting diodes (LEDs) monochromatic light. By: Muhammad Firdaus and Ahmad Fauzan

Spirulina is microalgae which is widely used as raw materials in chemical, food, and feed industries. Its production and chemical composition are very related with culture condition, such as the spectrum of light that is used. Monochromatic light with specific wavelength produced from light emitting diodes (LEDs) potentially to be implemented in microalgae culture. The aim of this research was to review effects of the LED wavelength on the production and nutritional content of Spirulina fusiformis. Spirulina was cultured using 2,000 Lux light from red (M), blue (B), and blue-red (BM) LEDs monochromatic light as well as fluorescens lamp as control (K). The peak of cell density occured at day-18, were 5.56 $\times 10^{4}$ cells $/ \mathrm{mL}(\mathrm{M}) ; 1.65 \times 10^{4}$ cells $/ \mathrm{mL}$ (B); $4.15 \times 10^{4}$ cells $/ \mathrm{mL}(\mathrm{BM}) ;$ and $4.56 \times 10^{4}$ cells $/ \mathrm{mL}(\mathrm{K})$, respectively. The highest production was achieved from Red LED monochromatic light with the biomass value of $3.91 \mathrm{mg} / \mathrm{mL}$, with the proteins content being $49.77 \%$, lipids $19.61 \%$, carbohydrate $6.15 \%$, fibre $0.00 \%$, and ash $24.48 \%$. Red LED light had a potential to be applied as light source in Spirulina production.

KEYWORDS: Spirulina fusiformis, LEDs, fluorescent lamp, production, nutritional value

\section{PENDAHULUAN}

Spirulina merupakan mikroalga yang termasuk kelompok sianobakteria dengan bentuk filamen. Komoditas ini telah dibudidayakan secara komersial karena laju pertumbuhan sel yang tinggi, prosedur pe-

\# Korespondensi: UPT Loka Pengembangan Bio Industri Laut, Pusat Penelitian Oseanografi, LIPI. Teluk Kodek, Melaka, Pamenang, Lombok Utara, Nusa Tenggara Barat 83352 E-mail: muhammad.firdaus@lipi.go.id manenan yang relatif mudah, dan potensi pasar yang besar. Kandungan berbagai senyawa penting seperti protein, mineral, vitamin, pigmen, serta asam lemak tidak jenuh menyebabkan Spirulina diminati sebagai bahan baku untuk industri kimia (biopigmen), pangan (suplemen dan nutrasetikal), dan pakan (Cifferi \& Tiboni, 1985; Cohen et al., 1987).

Spirulina bersifat fotoautotrof sehingga membutuhkan cahaya sebagai sumber energi untuk pertumbuhan sel dan sintesis berbagai substansi penting 
yang terlibat di dalamnya. Karakteristik sumber cahaya seperti panjang gelombang dan intensitas menjadi salah satu faktor kritis yang memengaruhi produksi Spirulina maupun mikroalga pada umumnya (Hirata et al., 1998; Chojnacka \& Nowortya, 2004; Blanken et al., 2013; Carvalho et al., 2011).

Produksi mikroalga dalam skala komersial umumnya menggunakan cahaya matahari sebagai sumber pencahayaan. Cahaya matahari dapat diperoleh secara bebas dan terdapat dalam jumlah melimpah sehingga dapat menekan biaya produksi. Meskipun demikian, penggunaannya dibatasi oleh siklus harian siang-malam, kerentanan terhadap perubahan cuaca dan musim, serta karakteristik lokasi (Blanken et al., 2013). Dinamika faktor-faktor tersebut dapat memengaruhi produktivitas dan kualitas produk yang dihasilkan.

Penggunaan cahaya dari sumber artifisial dalam produksi mikroalga merupakan alternatif yang layak dipertimbangkan. Kelebihan penggunaan cahaya artifisial adalah pencahayaan dapat disesuaikan dengan kebutuhan organisme kultur. Kuantitas dan kualitas pencahayaan yang tepat berpotensi meningkatkan produksi dan kualitas produk (Carvalho et al., 2011). Biaya produksi yang tinggi merupakan kelemahan utama penggunaan cahaya artifisial. Meskipun demikian, penggunaan cahaya artifisial dapat bernilai ekonomis jika biomassa yang dihasilkan digunakan sebagai bahan baku untuk memproduksi produk bernilai tinggi seperti suplemen pakan maupun pangan dan nutrasetikal (Blanken et al., 2013).

Jenis pencahayaan artifisial yang umum digunakan dalam kultur mikroalga adalah lampu fluoresens (lampu neon). Carvalho et al. (2011) menyatakan bahwa jenis lampu tersebut memancarkan spektrum cahaya polikromatis berwarna putih yang terdiri atas panjang gelombang berbeda. Kerugian dari aplikasi cahaya polikromatis adalah inefisiensi energi akibat turut dihasilkannya panjang gelombang cahaya tertentu yang memiliki aktivitas fotosintesis yang rendah.

Penggunaan gelombang cahaya tertentu yang dominan dalam proses fotosintesis maupun kombinasinya memberikan peluang yang menjanjikan untuk meningkatkan produksi (biomassa) maupun kualitas (kandungan nutrisi, pigmen, senyawa bioaktif) mikroalga, sekaligus merupakan salah satu cara meningkatkan efisiensi energi (Zhao et al., 2013; Yan et al., 2013).

Light emitting diodes (LEDs) merupakan kandidat sumber cahaya artifisial yang ideal. Beberapa karakteristik penting LEDs dibanding lampu fluoresens sebagai sumber cahaya artifisial dalam produksi mikroalga antara lain masa penggunaan lebih lama ( $\sim 50.000$ jam), bebas merkuri, lebih hemat energi, dan menghasilkan cahaya monokromatis dengan panjang gelombang tertentu (Blanken et al., 2013; Olle \& Virsile, 2013; Schulze et al., 2014).

Merujuk kepada Campbell et al. (2002) spektrum cahaya yang paling efektif diserap oleh klorofil sebagai sumber energi dalam reaksi terang adalah spektrum merah (630-700 nm) dan biru (400-480 nm). Penggunaan LED yang menghasilkan cahaya dengan panjang gelombang pada kisaran spektrum tersebut diduga dapat meningkatkan produksi dan kualitas Spirulina dibandingkan lampu fluoresens. Penelitian ini bertujuan untuk menganalisis pengaruh pencahayaan monokromatis LEDs (merah, biru, dan kombinasi merah-biru) dan lampu fluoresens (kontrol) terhadap produksi dan kandungan nutrisi S. fusiformis.

\section{BAHAN DAN METODE}

\section{Waktu dan Tempat}

Penelitian ini dilaksanakan pada bulan Februari hingga Mei 2011, bertempat di Laboratorium Nutrisi Ikan, Departemen Budidaya Perairan, Fakultas Perikanan dan Ilmu Kelautan, Institut Pertanian Bogor.

\section{Organisme Uji}

Spirulina fusiformis diperoleh dari koleksi Pusat Penelitian Limnologi LIPI, Cibinong dan selanjutnya ditumbuhkan dalam medium Zarrouk (Fauzan, 2012).

\section{Perlakuan Uji}

Spirulina dengan kepadatan awal $6.000 \mathrm{sel} / \mathrm{mL}$ dikultur dalam akuarium berdimensi $25 \mathrm{~cm}$ x $25 \mathrm{~cm}$ x $45 \mathrm{~cm}$ berisi 25 liter media, dengan fotoperiod 24 jam terang dan intensitas cahaya 2.000 lux. Penelitian menggunakan rancangan acak lengkap (RAL) dengan empat perlakuan dan masing-masing tiga ulangan. Perlakuan uji yang diberikan adalah pencahayaan monokromatis menggunakan LEDs (LED Panel, 1040 $5 \mathrm{~mm}$ Round LEDs, 24 Watt) berwarna merah (M) dengan panjang gelombang 635-650 nm, biru (B) dengan panjang gelombang 460-475 nm, dan kombinasi LED merah dan biru (BM) dengan komposisi 1:1. Lampu fluoresens putih (Philips TL-D 36W/865 1SL, 80 Ra8, Cool Daylight) digunakan sebagai kontrol. Skema penelitian dapat dilihat pada Gambar 1 .

\section{Parameter Produksi}

Parameter produksi Spirulina yang dihitung meliputi kepadatan sel, laju pertumbuhan, dan waktu penggandaan diukur setiap hari selama 20 hari perlakuan. Sedangkan produksi biomassa diukur di akhir perlakuan. 


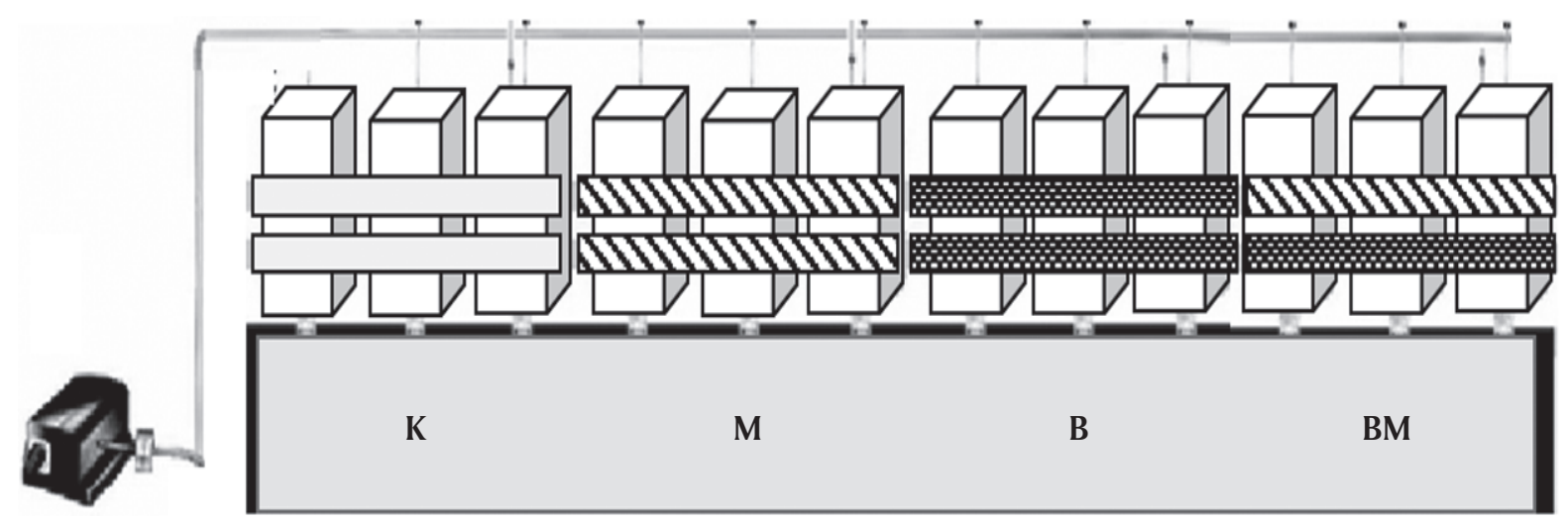

Gambar 1. Skema penelitian: kontrol pencahayaan fluoresens (K); perlakuan LED merah (M); perlakuan LED biru (B); perlakuan kombinasi LED merah dan biru (BM)

Figure 1. Research scheme: fluorescent light as control (K); red LED (M); blue LED (B); combination red and blue LEDs (BM)

\section{Kepadatan Sel}

Kepadatan sel Spirulina dihitung dengan bantuan hemositometer Neubauer Improved (Assistant, Germany) dan mikroskop Olympus BH-2 (Olympus, Japan) pada perbesaran lensa objektif 10x. Sampel sebanyak $1 \mathrm{~mL}$ diambil dari bagian tengah dengan kedalaman $20 \mathrm{~cm}$ dari permukaan. Pengamatan sel pada hemositometer dilakukan empat kali ulangan pada setiap bidang pandang hemositometer. Kepadatan sel dihitung menggunakan persamaan 1 (Fauzan, 2012).

$$
\mathrm{N}=\left(\mathrm{C} \times 10^{4}\right) /(\mathrm{A} \times \mathrm{D})
$$

di mana:

$\mathrm{N}=$ Kepadatan sel spirulina $\left(\mathrm{sel} \mathrm{mL}^{-1}\right)$

$\mathrm{C}=$ Jumlah sel yang dihitung

$A=$ Luas lapang pandang $\left(\mathrm{mm}^{2}\right)$

$\mathrm{D}=$ Kedalaman lapang pandang $(\mathrm{mm})$

\section{Laju Pertumbuhan Spesifik}

Laju pertumbuhan spesifik dihitung dengan menggunakan persamaan 2 (Vonshak, 1997).

$$
\mu=\left(\ln N_{t}-\ln N_{0}\right) / t
$$

di mana:

$\mu=$ Laju pertumbuhan spesifik (hari ${ }^{-1}$ )

$\mathrm{N}_{\mathrm{t}}=$ Kepadatan sel awal $\left(\right.$ sel $\left.\mathrm{mL}^{-1}\right)$

$\mathrm{N}_{0}=$ Kepadatan sel akhir $\left(\mathrm{sel} \mathrm{mL}^{-1}\right)$

$\mathrm{t}$ = Selang waktu dari $\mathrm{N}_{0}$ ke $\mathrm{N}_{\mathrm{t}}$ (hari)

\section{Waktu Penggandaan}

Waktu penggandaan populasi S. fusiformis dihitung menggunakan persamaan 3 (Vonshak, 1997).

$$
\mathrm{G}=\ln 2 / \mu=0,693 / \mu
$$

di mana:

$\mathrm{G}=$ Waktu penggandaan (hari)

$\mu=$ Laju pertumbuhan spesifik (hari ${ }^{-1}$ )

\section{Produksi Biomassa}

Produksi biomassa ditentukan secara gravimetri pada hari ke-20 perlakuan. Sampel sebanyak $15 \mathrm{~mL}$ disaring dengan kertas saring (Whatman GF/C 0,45 $\mu \mathrm{m})$, dikeringkan selama dua jam pada suhu $105^{\circ} \mathrm{C}$ dan selanjutnya ditimbang sebagai bobot akhir. Nilai biomassa diperoleh dari selisih antara bobot akhir dan bobot awal kertas saring (Vonshak, 1997).

\section{Kandungan Nutrisi}

Keseluruhan Spirulina untuk setiap perlakuan dan ulangan disaring sehingga diperoleh pasta, yang selanjutnya ditimbang sebagai bobot basah. Pasta Spirulina yang diperoleh dari setiap ulangan dalam perlakuan yang sama, kemudian digabung sebagai satu sampel (pool sample) untuk analisis proksimat. Analisis yang dilakukan meliputi kandungan lemak menggunakan metode Folch, kandungan protein menggunakan metode Kjeldahl, analisis kandungan abu dan air menggunakan metode gravimetri, serta analisis kandungan serat kasar (Takeuchi, 1988).

\section{Analisis Data}

Data parameter produksi (kepadatan sel, laju pertumbuhan spesifik, waktu penggandaan, serta produksi biomassa) dianalisis ragam (ANOVA) dan uji Tukey pada tingkat kepercayaan 95\%. Sedangkan data kandungan nutrisi dibahas secara deskriptif. Analisis data dilakukan dengan menggunakan perangkat lunak IBM SPSS Statistics 20.0.

\section{HASIL DAN BAHASAN}

\section{Parameter Produksi}

Perkembangan kepadatan sel S. fusiformis yang teramati dalam penelitian ini meliputi fase lag, fase eksponensial (fase logaritma), dan fase penurunan la- 
ju pertumbuhan (fase deklinasi). Ditinjau dari kurva kepadatan sel S. fusiformis selama 20 hari pemeliharaan (Gambar 2), terjadi perubahan kepadatan sel pada seluruh perlakuan yang diuji.

Fase lag pada perlakuan pencahayaan LED merah, LED biru-merah, dan kontrol berlangsung sekitar tiga hari, lebih singkat dibandingkan dengan perlakuan LED biru yang berlangsung hingga hari ke-6 (Gambar 2). Merujuk kepada Fogg (1975) fase tersebut terjadi karena energi yang dimiliki sel dipusatkan untuk penyesuaian diri terhadap kondisi kultur, serta menjaga metabolisme tetap stabil, akibatnya hanya sebagian kecil energi yang digunakan untuk pertumbuhan. Pada penelitian ini, kondisi tersebut dapat dilihat dari kepadatan sel yang relatif stagnan pada masa awal pemeliharaan.

Setelah fase lag, mikroalga memasuki fase eksponensial dengan ciri terjadinya peningkatan jumlah sel secara cepat. Pada penelitian ini, S. fusiformis dengan perlakuan pencahayaan LED merah, LED birumerah, dan kontrol mengalami fase eksponensial mulai hari ke-4 hingga hari ke-18. Pesatnya laju pertumbuhan menyebabkan meningkatnya kepadatan populasi beberapa kali lipat. Peningkatan populasi terjadi karena sel mikroalga aktif membelah dan membentuk protein, serta komponen-komponen penyusun plasma sel yang dibutuhkan dalam pertumbuhan (Vonshak, 1997). Perlakuan LED biru tidak menunjukkan terjadinya fase eksponensial, pertumbuhan yang terjadi pada perlakuan tersebut cenderung meningkat secara perlahan.

Kepadatan sel tertinggi S. fusiformis yang dikultivasi dengan berbagai perlakuan pencahayaan terjadi pada hari ke-18 (Gambar 3). Perbedaan sumber pencahayaan berpengaruh signifikan terhadap kepadatan sel $(\mathrm{P}<0,05)$. Perlakuan pencahayaan dengan LED merah menunjukkan hasil terbaik dengan kepadatan $5,56 \pm 0,19$ sel $\mathrm{mL}^{-1}$; sekitar $22 \%$ lebih tinggi jika dibandingkan dengan kontrol. Sementara, untuk perlakuan pencahayaan LED biru dan LED biru-merah masing-masing hanya sebesar 36\% dan 91\% dari kepadatan kontrol.

Secara teoritis, kepadatan sel dipengaruhi oleh laju pertumbuhan spesifik dan waktu penggandaan. Perbedaan sumber pencahayaan berpengaruh signifikan terhadap kedua parameter tersebut $(\mathrm{P}<0,05)$. Hasil penelitian memperlihatkan perlakuan pencahayaan LED merah konsisten memberikan hasil terbaik dengan laju pertumbuhan sebesar 0,114 hari $^{-1}$, walaupun tidak berbeda nyata dengan kontrol dan perlakuan pencahayaan dengan LED biru-merah. Meskipun demikian, berbeda nyata jika dibandingkan dengan laju pertumbuhan perlakuan pencahayaan LED biru yang hanya sekitar $42 \%$ dari LED merah (Tabel 1). Kecenderungan bahwa cahaya monokromatis merah bisa memacu laju pertumbuhan sejalan dengan hasil penelitian Wang et al. (2007) bahwa penggunaan LED merah (AL-R1001NR 620-645 nm, OSRAM, Jerman), dengan intensitas cahaya $3.000 \mu \mathrm{mol} \mathrm{m}{ }^{-2} \mathrm{~s}^{-1}(1 \mu \mathrm{mol}$ $\mathrm{m}^{-2} \mathrm{~s}^{-1}$ kurang lebih setara dengan 50 lux) dalam kultivasi $S$. platensis memberikan laju pertumbuhan spesifik tertinggi dengan nilai 0,40 hari $^{-1}$, hampir dua kali lipat jika dibandingkan LED putih, kuning, hijau, dan biru pada intensitas yang sama.

Dengan laju pertumbuhan yang tinggi, S. fusiformis pada perlakuan pencahayaan LED merah, LED biru-merah, dan kontrol memerlukan waktu sekitar

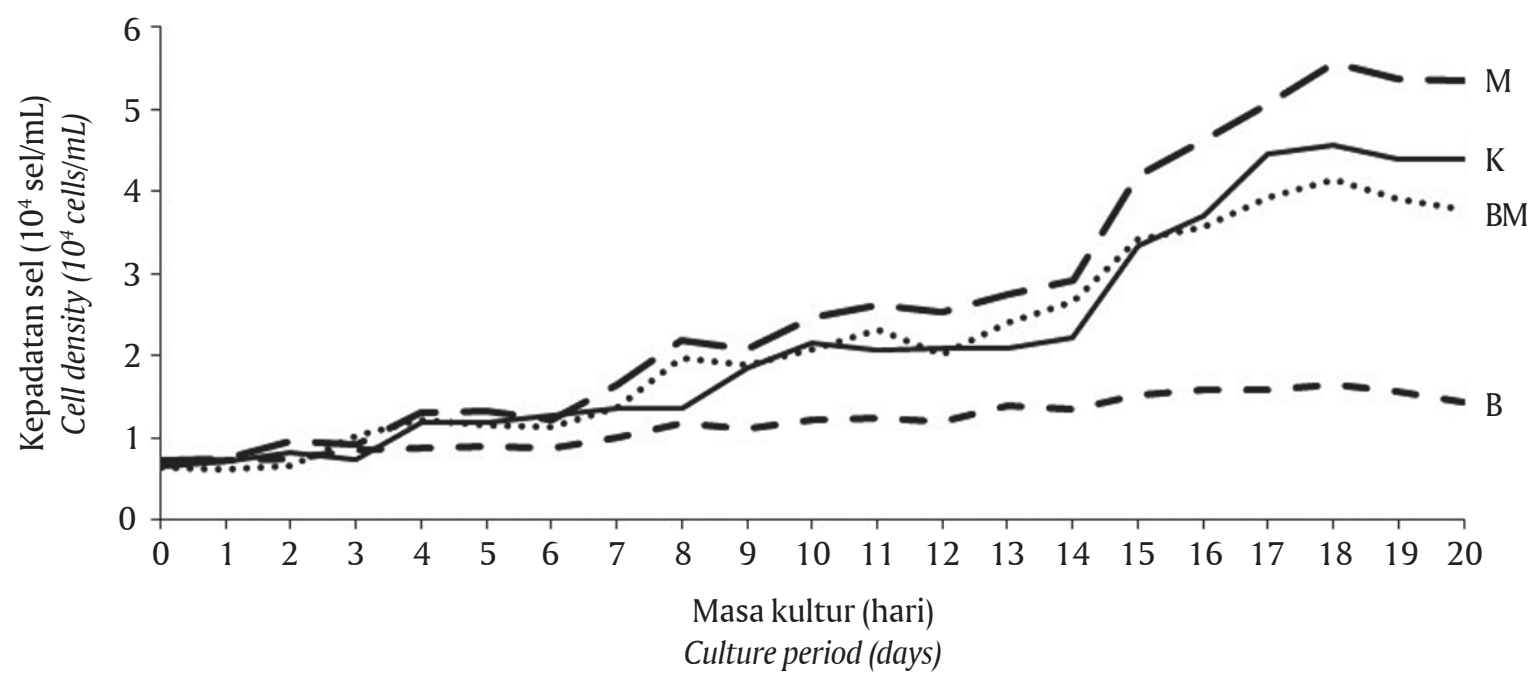

Gambar 2. Kepadatan sel Spirulina fusiformis selama kultivasi dengan perlakuan lampu fluoresens (K), LED merah (M), LED biru (B), dan LED biru merah (BM)

Figure 2. Cell density of Spirulina fusiformis during cultivation with lighting treatment using fluorescent light $(K)$, red LED $(M)$, blue LED (B), and blue-red LED (BM) 


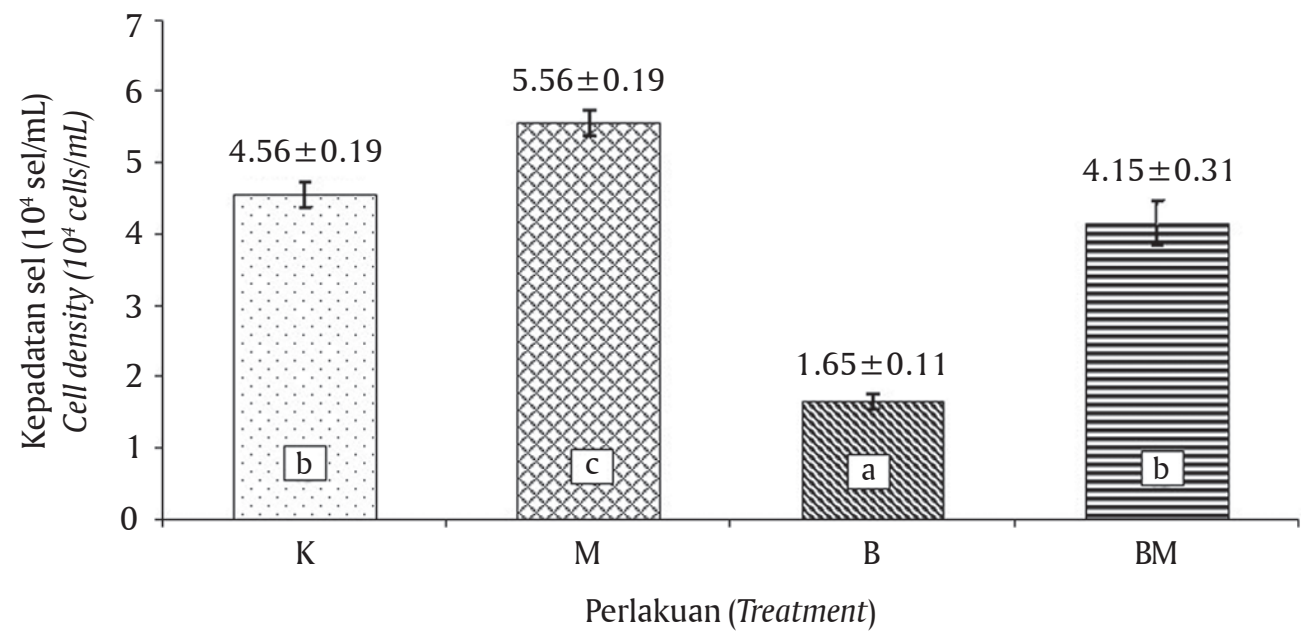

Keterangan (Note):

Huruf yang berbeda pada diagram menunjukkan perbedaan yang signifikan $(\mathrm{P}<0,05)$ (Different letters in diagram represent significantly differences $(P<0.05))$

Gambar 3. Kepadatan sel Spirulina fusiformis pada hari ke-18 dengan perlakuan pencahayaan lampu fluoresens sebagai kontrol (K), LED merah (M), LED biru (B), dan LED biru merah (BM)

Figure 3. Cell density of Spirulina fusiformis at day-18 using fluorescent light as control $(K)$, red $L E D(M)$, blue $L E D(B)$, and red-blue LEDs $(B M)$

Tabel 1. Laju pertumbuhan spesifik dan waktu penggandaan Spirulina fusiformis pada hari ke-18 dengan perlakuan pencahayaan lampu fluoresens sebagai kontrol (K), LED merah (M), LED biru (B), dan LED biru merah (BM)

Table 1. Specific growth rate and doubling time of Spirulina fusiformis at day-18 using fluorescent light as control $(K)$; red LED (M); blue LED (B); and red-blue LEDs (BM)

\begin{tabular}{|c|c|c|c|c|}
\hline \multirow{2}{*}{$\begin{array}{l}\text { Sumber pencahayaan } \\
\text { Lighting source }\end{array}$} & \multicolumn{2}{|c|}{$\begin{array}{c}\text { Rerata kepadatan sel }\left(10^{4} \mathrm{sel} \mathrm{mL}^{-1}\right) \\
\text { Cell density average }\left(10^{4} \text { cell } \mathrm{mL}^{-1}\right)\end{array}$} & \multirow{2}{*}{$\begin{array}{l}\text { Laju pertumbuhan } \\
\text { spesifik (hari-1 } \\
\text { Specific growth rate } \\
\text { (day-1) }\end{array}$} & \multirow{2}{*}{$\begin{array}{c}\text { Waktu penggandaan } \\
\text { (hari) } \\
\text { Doubling time (day) }\end{array}$} \\
\hline & $\begin{array}{c}\text { Hari ke-0 } \\
\text { Day-0 }\end{array}$ & $\begin{array}{l}\text { Hari ke-18 } \\
\text { Day-18 }\end{array}$ & & \\
\hline $\begin{array}{l}\text { Kontrol (Lampu fluoresens) } \\
\text { Control (Fluorescent lamp) }\end{array}$ & $0.657 \pm 0.153$ & $4.558 \pm 0.185^{\mathrm{b}}$ & $0.109 \pm 0.011^{\mathrm{b}}$ & $6.429 \pm 0.662^{\mathrm{a}}$ \\
\hline LED merah (Red LED) & $0.722 \pm 0.096$ & $5.559 \pm 0.188^{c}$ & $0.114 \pm 0.006^{b}$ & $6.106 \pm 0.305^{\mathrm{a}}$ \\
\hline LED biru (Blue LED) & $0.702 \pm 0.018$ & $1.654 \pm 0.113^{\mathrm{a}}$ & $0.048 \pm 0.003^{\mathrm{a}}$ & $14.62 \pm 1.019^{b}$ \\
\hline LED biru-merah (Blue-red LED) & $0.631 \pm 0.043$ & $4.147 \pm 0.311^{\mathrm{b}}$ & $0.105 \pm 0.007^{\mathrm{b}}$ & $6.651 \pm 0.454^{\mathrm{a}}$ \\
\hline
\end{tabular}

Keterangan (Note):

Huruf superscript yang berbeda pada parameter dan kolom yang sama menunjukkan perbedaan yang signifikan $(\mathrm{P}<0,05)($ Different superscript letters in the same parameter and column represent significantly differences $(P<0.05))$

enam hari untuk melipatgandakan populasinya. Sebaliknya, waktu penggandaan secara nyata berbeda untuk perlakuan pencahayaan LED biru yang memerlukan waktu 14 hari karena dipengaruhi laju pertumbuhan yang rendah (Tabel 1).

Setelah hari ke-19, mulai terjadi penurunan kepadatan sel pada semua perlakuan yang diujikan dalam penelitian ini (fase deklinasi) (Gambar 2). Fase ini terjadi akibat kekurangan nutrisi (nitrogen dan fosfat), menurunnya konsentrasi $\mathrm{CO}_{2}$ atau $\mathrm{O}_{2}$ terlarut, serta kenaikan pH media. Menurut Richmond \& Grobbelaar (1986), fase ini juga dapat terjadi karena penurunan intensitas cahaya yang dapat diterima akibat pembentukan bayangan (self-shading), serta proses autoinhibition yaitu kemampuan sel menghasilkan senyawa penghambat pertumbuhan.

Biomassa panen S. fusiformis untuk masing-masing perlakuan dipengaruhi secara signifikan oleh sumber pencahayaan $(\mathrm{P}<0,05)$. Hasil yang diperoleh menunjukkan pola yang sama dengan kepadatan sel, laju 
pertumbuhan, dan waktu penggandaan. Biomassa panen tertinggi sebesar 3,91 $\pm 0,15 \mathrm{mg} / \mathrm{mL}$ diperoleh pada perlakuan pencahayaan LED merah, yang berbeda secara nyata dengan perlakuan lainnya. Hasil tersebut lebih tinggi sekitar 30\% dibandingkan kontrol, $32 \%$ dibandingkan dengan LED biru-merah, dan 220\% dibandingkan dengan LED biru (Gambar 4). Biomassa panen yang diperoleh dalam penelitian ini lebih tinggi jika dibandingkan dengan hasil yang diperoleh Chen et al. (2010) pada kultivasi S. platensis, yaitu sebesar $0,45 \mathrm{mg} / \mathrm{mL}$. Pada penelitian tersebut, biomassa yang diperoleh dari perlakuan pencahayaan dengan LED merah dengan intensitas $3.000 \mu \mathrm{mol} \mathrm{m}^{-2} \mathrm{~s}^{-1}$ lebih tinggi dibandingkan dengan LED putih, kuning, hijau, dan biru.

Secara umum, meskipun intensitas cahaya yang digunakan dalam penelitian ini sama besarnya untuk semua perlakuan dan kontrol (2.000 lux), perbedaan sumber pencahayaan berpengaruh secara signifikan terhadap aspek produksi yang diwakili kepadatan sel, laju pertumbuhan spesifik, waktu penggandaan, dan biomassa panen. Perbedaan tersebut terjadi akibat pengaruh kualitas cahaya (panjang gelombang) yang berasal dari LED sebagai sumber pencahayaan monokromatis. Karakteristik sumber cahaya seperti panjang gelombang dan intensitas menjadi salah satu faktor kritis yang memengaruhi proses fotosintesis. Spirulina merupakan organisme fotoautotrof yang melakukan proses fotosintesis untuk memperoleh energi yang diperlukan dalam metabolisme. Fotosintesis merupakan proses kompleks yang dipengaruhi oleh berbagai variabel baik internal maupun eksternal yang selanjutnya akan berdampak terhadap produksi Spirulina (Park \& Lee, 2000).

Ditinjau dari aspek efisiensi pemanfaatan cahaya oleh kloroplas mikroalga, diketahui bahwa mikroalga menyerap semua cahaya yang diterima walaupun tidak semua foton dapat dimanfaatkan (Park \& Lee, 2000). Hal tersebut tercermin pada hasil penelitian yang memperlihatkan variasi pada setiap perlakuan yang diujikan. Jumlah foton pada panjang gelombang biru atau merah yang dapat ditangkap oleh molekul klorofil mikroalga bergantung pada struktur sel, komposisi pigmen dan susunan kloroplas (Schulze et al., 2014).

Komposisi pigmen pada light-harvesting proteinpigment (LHP) complexes kloroplas sianobakteria, terutama pada kelompok yang tidak memiliki klorofil $\beta$, didominasi klorofil $\alpha$ (panjang gelombang maksimum yang diserap $430 \mathrm{~nm}$ dan $680 \mathrm{~nm}$ ) dan fikobiliprotein tambahan seperti fikoeritrin (panjang gelombang maksimum yang diserap $550 \mathrm{~nm}$ ), serta fikosianin (panjang gelombang maksimum yang diserap $620 \mathrm{~nm}$ ) (Marriot \& Blankenship, 2011). Akibatnya, sianobakter mampu memanfaatkan spektrum cahaya merah, kuning, dan hijau, serta biru pada proporsi yang lebih rendah (Chen et al., 2010; Itoh et al., 2014).

Spektrum cahaya biru yang terpapar pada S. fusiformis tidak dikonversi menjadi senyawa kimiawi atau energi untuk metabolisme, tetapi cenderung dipantulkan kembali atau diserap dalam proporsi yang

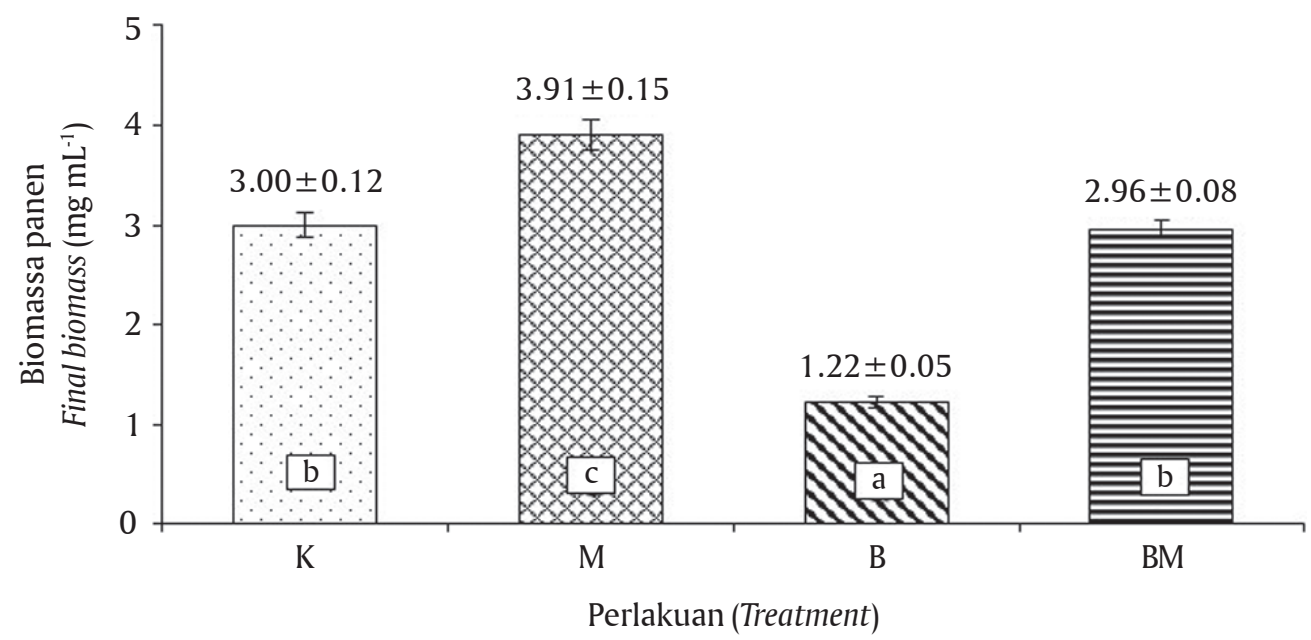

Keterangan (Note):

Huruf yang berbeda pada diagram menunjukkan perbedaan yang signifikan $(\mathrm{P}<0,05)$ (Different letters in diagram represent significantly differences $(P<0.05))$

Gambar 4. Biomassa panen Spirulina fusiformis dengan perlakuan pencahayaan lampu fluoresens sebagai kontrol (K), LED merah (M), LED biru (B), dan LED biru merah (BM)

Figure 4. Final biomass of Spirulina fusiformis cultured using fluorescent light as control $(K)$, red $L E D(M)$, blue $L E D(B)$; and red-blue LEDs (BM) 
rendah. Hal tersebut menjelaskan bahwa spektrum merah lebih efektif dimanfaatkan oleh Spirulina dalam proses fotosintesis sehingga menghasilkan performa produksi terbaik (kepadatan sel, laju pertumbuhan spesifik, waktu penggandaan, dan biomassa). Sebaliknya, perlakuan cahaya biru tidak menunjukkan hasil pertumbuhan yang baik. Sementara untuk kontrol berupa pencahayaan dengan lampu fluoresen, produksi yang dihasilkan relatif tinggi, meskipun memiliki efisiensi yang rendah. Efisiensi tersebut disebabkan lampu fluoresen menghasilkan spektrum polikromatis dengan kisaran panjang gelombang yang luas, padahal hanya gelombang tertentu yang bisa diserap dan dimanfaatkan oleh sel Spirulina untuk proses fotosintesis (Carvalho et al., 2011). Hasil yang diperoleh pada penelitian ini, sejalan dengan Farges et al. (2009) yang melaporkan bahwa efisiensi pencahayaan terbaik dalam kultur $S$. platensis diperoleh pada penyinaran cahaya monokromatis merah pada kisaran panjang gelombang $618-626 \mathrm{~nm}$.

\section{Kandungan Nutrisi}

Selain biomassa panen, kandungan nutrisi merupakan parameter penting yang menentukan kualitas produk. Perlakuan pencahayaan dengan LED merah, LED biru, LED biru-merah, dan lampu fluoresens sebagai kontrol, menyebabkan terjadinya perbedaan komposisi nutrisi pada biomassa S. fusiformis (Tabel 2). Berdasarkan kandungan protein dan lemak yang merupakan substansi target dalam budidaya Spiruli$n a$, perlakuan pencahayaan dengan LED merah menunjukkan performa terbaik dibandingkan dengan perlakuan LED biru dan LED biru-merah. Sementara dibandingkan dengan kandungan protein dan lemak kontrol, perbedaannya tidak terlampau jauh yaitu lebih rendah $2 \%$ untuk protein dan sekitar $1 \%$ untuk kandungan lemak. Sebaliknya, untuk perlakuan pencahayaan LED biru dan LED biru-merah menunjukkan kandungan protein yang jauh lebih rendah yaitu $34 \%$ dan $40 \%$ dibandingkan dengan kontrol.
Kandungan protein S. fusiformis dari semua perlakuan pencahayaan lebih rendah jika dibandingkan hasil penelitian Rafiqul et al. (2005) pada jenis S. platensis yang menghasilkan nilai protein hingga $61,8 \%$. Sementara untuk kandungan lemak, nilai yang diperoleh lebih tinggi dibandingkan jenis S. platensis yang menghasilkan kandungan lemak sebesar $8,2 \%$ pada penelitian yang sama.

Karbohidrat, abu, dan serat kasar bukan merupakan substansi target dalam produksi Spirulina sehingga komposisinya diharapkan bisa ditekan. Kandungan karbohidrat pada perlakuan pencahayaan LED biru-merah lebih tinggi $217 \%$ dari perlakuan pencahayaan LED biru, $688 \%$ dibandingkan LED merah, dan $882 \%$ dibanding lampu fluoresens. Kandungan karbohidrat pada perlakuan LED merah dan kontrol $<10 \%$, dilihat dari parameter ini kedua perlakuan tersebut menunjukkan hasil terbaik. Sebaliknya untuk perlakuan pencahayaan LED biru dan LED biru-merah kadar karbohidrat relatif tinggi, sehingga berpeluang menurunkan nilai ekonomis produk yang dihasilkan.

Kandungan abu pada biomassa Spirulina relatif seragam untuk perlakuan pencahayaan LED merah, LED biru-merah, dan kontrol yaitu pada kisaran $24 \%$. Sedangkan pada perlakuan pencahayaan LED biru, kandungan abu mencapai hampir dua kali lipat dibandingkan perlakuan lain. Akumulasi abu pada perlakuan pencahayaan LED biru bahkan melebihi persentase kandungan protein, lemak, karbohidrat, dan serat kasar. Kandungan serat kasar hanya terdapat pada perlakuan pencahayaan LED biru-merah dengan persentase yang relatif rendah, yaitu 1,91\% dari keseluruhan biomassa kering.

Penggunaan sumber pencahayaan yang berbeda, menunjukkan pengaruh terhadap komposisi nutrisi Spirulina. Diduga bahwa penggunaan sumber cahaya yang berbeda memengaruhi proses fisiologis dalam sel Spirulina, dan berakibat pada perbedaan jenis nutrisi yang diakumulasi dalam sel. Meskipun demiki-

Tabel 2. Hasil analisis proksimat Spirulina fusiformis

Table 2. Proximate analysis of Spirulina fusiformis

\begin{tabular}{lcccc}
\hline \multirow{2}{*}{$\begin{array}{c}\text { Jenis nutrisi } \\
\text { Nutrition }\end{array}$} & \multicolumn{4}{c}{$\begin{array}{c}\text { Nilai nutrisi (\% per bobot kering) } \\
\text { Nutritional content (\% dry weight) }\end{array}$} \\
\cline { 2 - 5 } & $\begin{array}{c}\text { Kontrol } \\
\text { Control }\end{array}$ & $\begin{array}{c}\text { LED merah } \\
\text { Red LED }\end{array}$ & $\begin{array}{c}\text { LED biru } \\
\text { Blue LED }\end{array}$ & $\begin{array}{c}\text { LED biru-merah } \\
\text { Blue-red LED }\end{array}$ \\
\hline Protein (Protein) & 50.66 & 49.77 & 20.54 & 17.15 \\
Lemak (Lipid) & 20.31 & 19.6 & 19.44 & 15.05 \\
Karbohidrat (Carbohydrate) & 4.80 & 6.15 & 19.44 & 42.32 \\
Abu (Ash) & 24.24 & 24.48 & 40.59 & 23.57 \\
Serat kasar (Crude fibre) & 0.00 & 0.00 & 0.00 & 1.91 \\
\hline
\end{tabular}


an, diperlukan penelitian lanjutan yang lebih mendalam mengenai proses tersebut.

\section{KESIMPULAN}

Perbedaan sumber pencahayaan berpengaruh secara signifikan terhadap aspek produksi yang diwakili kepadatan sel, laju pertumbuhan spesifik, waktu penggandaan, dan biomassa panen. Pencahayaan menggunakan LED merah secara konsisten menghasilkan produksi Spirulina tertinggi dibandingkan perlakuan pencahayan dengan lampu fluoresens, LED biru-merah, dan LED biru. Komposisi nutrisi pada produk yang dihasilkan dari pencahayaan LED merah memiliki proporsi mendekati kondisi normal (kontrol). Secara umum, LED merah layak diterapkan sebagai sumber pencahayaan alternatif dalam produksi S. fusiformis.

\section{UCAPAN TERIMA KASIH}

Penulis menyampaikan terima kasih pada Drs. Tjandra Chrismadha, M.Sc. yang telah membantu dalam penyediaan inokulan Spirulina fusiformis, Dr. Nur Bambang Priyo Utomo yang membantu penyediaan formula pupuk Zarrouk, Prof. Dr. Gono Semiadi atas bimbingan dalam penulisan makalah ini, serta kepada Heru Ahen Priatna, Aditya Hikmat Nugraha, dan Putri Zulfania atas bantuan teknis dalam pelaksanaan penelitian. Pembiayaan kegiatan penelitian ini berasal dari hibah PKM DIKTI Tahun 2011.

\section{DAFTAR ACUAN}

Blanken, W., Cuaresma, M., Wijffels R.H., \& Janssen, M. (2013). Cultivation of microalgae on artificial light comes at a cost. Mikroalgal. Res., 2, 333-340.

Campbell, N.A., Reece, J.B., \& Mitchell, L.G. (2002). Biologi. Edisi Kelima-jilid 1. Erlangga. Jakarta, xxi $+438 \mathrm{hlm}$.

Carvalho, A.P., Silva, S.O., Baptista, J.M., \& Malacata, F.X. (2011). Light requirements in microalgal photobioreactors: an overview of biophotonic aspects. Appl. Microbiol. Biotechnol., 89, 1,275-1,288.

Chen, H.B. Wanga, C.Y., \& Liua, Y.C. (2010). Modeling on chlorophyll a and phycocyanin production by Spirulina platensis under various light-emitting diodes. Biochem. Eng. J., 53, 52-56.

Chojnacka, K., \& Noworyta, A. (2004). Evaluation of Spirulina sp. growth in photoautotrophic, heterotrophic, and mixotrophic cultures. Enzyme Microb. Technol., 34, 461-465.

Ciferri, O., \& Tiboni, O. (1985). The biochemistry and industrial potential of Spirulina. Annu. Rev. Microbiol., 39, 503-526.

Cohen, Z., Vonshak, A., \& Richmond, A. (1987). Fattyacid composition of Spirulina strains grown un- der various environmental conditions. Phytochemistry, 26, 2,255-2,258.

Farges, B., Laroche, C., Cornet, J.F., \& Dussap C.G. (2009). Spectral kinetic modeling and long-term behavior assessment of Arthrospira platensis growth in photobioreactor under red $(620 \mathrm{~nm})$ light illumination. Biotechnol. Prog., 25(1), 152-162.

Fauzan, A. (2012). Teknologi produksi Spirulina fusiformis secara intensif dengan pencahayaan monospektrum. Skripsi. Departemen Budidaya Perairan, Fakultas Perikanan dan Ilmu Kelautan, Institut Pertanian Bogor, Bogor, $26 \mathrm{hlm}$.

Fogg, G.E. (1975). Algal culture and phytoplankton ecology. The University of Winsconsin Press. London, $175 \mathrm{pp}$.

Hirata, S., Taya, M., \& Tone, S. (1998). Continuous culture of Spirulina platensis under photoautotrophic conditions with change in light intensity. J. Chem. Eng. Jpn., 31, 636-639.

Itoh, K.I., Nakamura, K., Aoyama, T., Kakimoto, T., Murakami, M., \& Takido, T. (2014). The influence of wavelength of light on cyanobacterial asymmetric reduction of ketone. Tetrahedron Lett., 55, 435-437.

Marriott, M.F.H., \& Blankenship, R.E. (2011). Evolution of photosynthesis. Annu. Rev. Plant Biol., 62, 515-548.

Olle, M., \& Virsile, A. (2013). The effects of lightemitting diode lighting on greenhouse plant growth and quality. Agric. Food Sci., 22, 223-234.

Park, K.H., \& Lee, C.G. (2000). Optimization of algal photobioreactors using flashing lights. J. Biotechnol. Bioprocess Eng., 5, 186-190.

Rafiqul, I.M., Jalal, K.C.A., \& Alam, M.Z. (2005). Environmental factors for optimalization of Spirulina biomass in laboratory culture. Asian Network for Scientific Information Biotechnology, 4(1), 19-22.

Richmond, A., \& Grobbelaar, J.U. (1986). Factors affecting the output rate of Spirulina platensis with reference to mass cultivation. Biomass, 10, 253264.

Schulze, P.S.C., Barreira, L.A., Pereira, H.G.C. Perales, J.A., \& Varela, J.C.S. (2014). Light emitting diodes (LEDs) applied to microalgal production. Trends in Biotechnology, 32(8), 422-430.

Takeuchi, T. (1988). Laboratory work chemical evaluation of dietary nutriens. In Watanabe T. (Ed.), Fish Nutrition and Mariculture. Department of Aquatic Bioscience, Tokyo University of Fisheries-JICA. Tokyo, p. 179-226.

Vonshak, A. (1997). Spirulina: growth, physiology and biochemistry. In Vonshak, A. (Ed.), Spirulina platensis (Arthrospira): physiology, cell-biology and biotechnology. Taylor and Francis Ltd. Bristol, p. 46- 
47.

Wang, C.Y., Fu, C.C., \& Liu, Y.C. (2007). Effects of using light-emitting diodes on the cultivation of Spirulina platensis. Biochemical Engineering Journal, 37, 21-25.

Yan, C., Zhang, L., Luo, X., \& Zheng, Z. (2013). Effects of various LED light wavelengths and intensities on the performance of purifying synthetic domestic sewage by microalgae at different influent C/N ratios. Ecol. Eng., 51, 24-32.

Zhao, Y., Wang, J., Zhang, H., Yan, C., \& Zhang, Y. (2013). Effects of various LED light wavelengths and intensities on microalgae-based simultaneous biogas upgrading and digestate nutrient reduction process. Bioresour. Technol., 136, 461-468. 